
Основні напрями вдосконалення законодавчого закріплення організації паркування та
зберігання транспортних засобів в Україні в контексті урахування зарубіжного досвіду

Соколенко Д. В.

аспірант кафедри адміністративного та господарського права

Запорізький начіональний університет

вул. Жуковського, 66, Запоріжжя, Україна

orcid.org/0000-0002-3570-6092

den.sokolenko@gmail.com

Ключові слова: паркування, паркувальні майданчики, паркувальні зони, платні парковки, паркування транспортних засобів, зберігання транспортних засобів, транспортний засіб, автомобільний транспорт, паркінг, автостоянка, парковка.
У статті проаналізовано національне та зарубіжне законодавство у сфері паркування та зберігання автомобільних транспортних засобів. Визначено, що Україна, як сучасна правова держава, вибрала пріоритетний вектор розвитку на вступ до Європейського Союзу, зокрема, шляхом адаптації українського законодавства у сфері паркування та зберігання автомобільних транспортних засобів до європейських та міжнародних стандартів, що повинно неодмінно покращити комфортність життя громадян України. Предметом цього дослідження $\epsilon$ напрями вдосконалення законодавчого регулювання сфери паркування та зберігання автомобільних транспортних засобів 3 урахуванням успішного закордонного досвіду, який підходить для впровадження в Україні. Об'єктом дослідження є суспільні відносини, які виникають у сфері паркування та зберігання автомобільних транспортних засобів та потребують чіткого законодавчого врегулювання. У межах дослідження здійснено порівняльно-правовий аналіз наукової літератури, нормативних актів зарубіжних країн, з яких можна умовно виокремити декілька світових моделей правового регулювання організації паркування та зберігання транспортних засобів, та вибрано найбільш ефективну модель, яка найбільше підходить для впровадження в Україні. Розкрито основні пріоритетні напрями державної політики України щодо впорядкування нормативно-правової бази паркування та зберігання автомобільних транспортних засобів, які визначені в Національній транспортній стратегії України на період до 2030 року від 30.05.2018 № 430-p. Зроблено висновок про необхідність упровадження до національного законодавства європейських практик з організації паркування та зберігання автомобільних транспортних засобів, основною з яких є розширення повноважень органів місцевого самоврядування у цій сфері та впровадження інституту державно-приватного партнерства. На основі дослідженої інформації обгрунтовано необхідність проведення кодифікації законодавства у цій сфері та створення Закону України «Про паркування», який би містив загальні норми, що визначають цілі та принципи правового регулювання суспільних відносин у цій галузі, а також забезпечував взаємоузгодженість усіх норм інших галузей, які застосовуються у правовому регулюванні паркування та зберігання транспортних засобів. Одним із головних завдань цього Закону $\epsilon$ врегулювання колізії, пов'язаної з визначенням понять та закріпленням єдиного підходу до впровадження реформи з паркування. 


\title{
Main directions of improvement of legislative confirmation of parking organization and storage of vehicles in Ukraine in the context of account of foreign expirience
}

\author{
Sokolenko D. V. \\ Postgraduate Student at the Department of Administrative and Commercial Law \\ Zaporizhzhia National University \\ Zhukovskoho str., 66, Zaporizhzhia, Ukraine \\ orcid.org/0000-0002-3570-6092 \\ den.sokolenko@gmail.com
}

Key words: parkings, parking lots, parking zones, paid parkings, parkings of vehicles, storage of vehicles, vehicle, road transport, field of parking, parking.

\begin{abstract}
The article analyzes national and foreign legislation in the field of parking and storage of motor vehicles. It is determined that Ukraine, as a modern state governed by the rule of law, has chosen a priority vector of development for accession to the European Union, in particular, by adapting Ukrainian legislation in the zone of parking and storage of vehicles to European and international standards. The subject of this study is to improve the legislative regulation of parking and storage of vehicles, taking into account the successful foreign experience, which is suitable for implementation in Ukraine. The object of the study is public relations that arise in the field of parking and storage of vehicles, and require a clear legal regulation. The study conducted a comparative legal analysis of scientific literature, regulations of foreign countries, from which we can distinguish several global models of legal regulation of parking and storage of vehicles and selected the most effective model that is most suitable for implementation in Ukraine. The main priority areas of the state policy of Ukraine on streamlining the regulatory framework for parking and storage of motor vehicles, which are defined in the National Transport Strategy of Ukraine for the period up to 2030 from 30.05.2018 No. 430-r. It is concluded that it is necessary to introduce into national legislation European practices for parking and storage of motor vehicles, the main of which is to expand the powers of local governments in this area and the introduction of public-private partnership. On the basis of the researched information the necessity of codification of the legislation in this sphere and to create the Law of Ukraine "About parking" which would contain the general norms defining the purposes and principles of legal regulation of public relations in this branch, and also are used in the legal regulation of parking and storage of vehicles. One of the main tasks of this law is to resolve the conflict related to the definition of concepts and to consolidate a unified approach to the implementation of parking reform.
\end{abstract}

\begin{abstract}
Актуальність досліджуваної теми. Україна, вибравши європейський вектор розвитку, взяла на себе обов'язок приведення українського законодавства у сфері паркування та зберігання автомобільних транспортних засобів до європейських та міжнародних стандартів. 3 огляду на проєвропейську спрямованість політики нашої держави постала необхідність впровадження до національного законодавства європейських практик з паркування та зберігання автомобільних транспортних засобів, яка зумовила потребу в розширенні повноважень органів місцевого самоврядування у цій сфері, розвитку інституту державно-приватного партнерства та спричинила гостру необхідність реформування законодавства у такій сфері.
\end{abstract}

Внаслідок відсутності чіткого законодавчого врегулювання такої сфери держава втрачає значні надходження до бюджетів різних рівнів та отримує неконтрольовану ситуацію зі стихійним паркуванням. Запровадження європейських стандартів в Україні пов'язане 3 необхідністю вирішення низки питань 3 удосконалення правового регулювання паркування та зберігання автомобільних транспортних засобів і встановлення чіткого адміністративно-правового механізму регулювання такої сфери.

Мета статті - комплексно проаналізувати особливості правового регулювання паркування та зберігання автомобільних транспортних засобів у країнах Європейського Союзу із 
визначенням сутності, змісту та механізму адміністративно-правового регулювання, запропонувати найактуальнішу модель для впровадження в Україні.

Виклад основного матеріалу. Аналізуючи нормативні акти зарубіжних країн, можна умовно виокремити декілька європейських та світових моделей правового регулювання організації паркування та зберігання транспортних засобів.

Перша модель (Бельгія, Фінляндія, Німеччина, Іспанія) полягає в поділі міста на декілька зон з різними умовами паркування. Наприклад, м. Хельсінкі (Фінляндія) розділено на три зони, ціни за паркування в яких диференціюються залежно від того, на якій відстані від центру міста ця зона знаходиться. Подібним чином організоване паркування в Брюсселі (Бельгія), де існує поділ міста на «сині» та «жовті» зони. Паркування дозволяється виключно в «синіх» зонах, де стягується погодинна плата за паркування. У разі ж коли водій залишив свій транспортний засіб поза «синіми» зонами або в межах заборонених «жовтих» зон, то його транспортний засіб підлягає евакуації [4]. Дещо по-іншому реалізована така модель у Німеччині. Так, наприклад, у м. Берліні найвища плата за паркування стягується в центрі міста. Крім того, в центрі міста час паркування обмежений до 15 хв. У районах, наближених до центру, паркування вже не обмежене у часі та здійснюється за значно нижчими тарифами. На околицях же міста функціонують безкоштовні паркінги [3, с. 6].

Друга модель (Нідерланди, Чехія) полягає у зменшенні кількості транспортних засобів у центрі міста за рахунок будівництва перехоплюючих паркінгів, або як їх ще називають паркування P+R типу "Park\&Ride" (Паркуй та Їдь). Такі паркінги, як правило, розташовані в під’їних зонах до центру великих міст або в передмісті та сполучені з громадським транспортом, що дозволяє жителям приміської зони та іншим людям вирушати в центр міста, залишивши свої транспортні засоби та пересівши в автобус, маршрутне таксі, трамвай, метро тощо на решту подорожі. Автомобіль зберігається на паркуванні протягом дня i забирається власником на зворотному шляху. Так, у Празі (Чехія) побудовано 17 таких паркінгів. Плата за паркування на них значно дешевша ніж на паркування в центрі міста. В Амстердамі (Нідерланди) є 7 таких паркінгів. Під час паркування на цих паркінгах водій та пасажири (до 5 осіб) отримують безкоштовні квитки до центру міста [3, с. 6].

Третя модель (Великобританія, Норвегія) полягає у запровадженні обмеження використання індивідуальних автомобілів у центральній частині міст. Наприклад, у м. Лондоні (Великобританія) організовано платний в’їзд у центр, крім того, в центрі протягом робочого дня по буднях і в першій половині дня по суботах заборонено паркувати транспортні засоби. На вулицях в інших частинах міста паркування вдень i по буднях платне та обмежене за часом, оплачувати його потрібно через паркомати або за допомогою мобільного додатка [2].

Четверта модель (США, Португалія) полягає в будівництві підземних та наземних багаторівневих паркінгів у центральних районах міст та місцях найбільшої концентрації транспортних засобів. Прикладом такої моделі є м. Нью-Йорк (США), де значна кількість підземних та надземних багаторівневих паркінгів. Плата за паркування на цих паркінгах $є$ значно меншою ніж на вуличних паркінгах, крім того, на більшості вуличних паркінгів час перебування транспортних засобів обмежений, а штрафи за перевищення цього часу є дуже великими [6, с. 36-37; 7, с. 7].

П'ята модель (Грузія, Литва, Ірландія) полягає в тому, що врегулювання паркування обмежується лише обладнанням уже наявних паркінгів паркоматами, через які здійснюється оплата послуг за паркування, організацією контролю за дотриманням правил паркування спеціально уповноваженими особами та встановленні жорстких санкцій за порушення цих правил [6, с. 35]. Необхідно зазначити, що ця модель правового регулювання організації паркування та зберігання транспортних засобів натепер застосовується і в Україні.

Шосту модель (Польща, Франція) можна назвати змішаною, оскільки вона включає у себе застосування державою одразу декількох заходів, що притаманні різним моделям правового регулювання організації паркування та зберігання транспортних засобів. Так, наприклад, у Парижі (Франція) поряд 3 поділом міста на «блакитну» (для короткочасної парковки), «зелену» (для тривалого паркування) та «червону» (де паркування заборонено) зони відбувається активне будівництво на околиці міста, біля станцій метро перехоплюючих паркінгів [3, с. 7]. Подібним чином здійснюється організація паркування і в містах Польщі, але, окрім зонування міста та будівництва перехоплюючих стоянок на околицях містах, тут ще й активно будують підземні паркінги у центральних районах міста $[9 ; 5]$.

Окремо від цих усіх моделей необхідно виділити досвід Канади, в якій активно впроваджуються цифрові технології для організації та оплати паркування. Так, у країні активно тестується пристрій під назвою "РауBySky", який встановлюється у бортову систему діагностики транспортного засобу. За допомогою такого пристрою відбувається пошук вільної платної парковки, результати якого виводяться на смартфон водія. Після того, як водій забирає автомобіль 
3 парковки, пристрій нараховує плату за неї та виставляє рахунок, який можна оплатити за допомогою цього ж смартфона $[2 ; 8]$.

Серед зазначених вище моделей необхідно виділити модель правового регулювання паркування та зберігання транспортних засобів, що сформувалася в Польщі, яка, зважаючи на спільні риси містобудування, схожі початкові умови, за яких відбувся початок реформування галузі паркування, а також тісні економічні та політичні зв'язки, є найбільш пріоритетною для майбутнього впровадження в нашій державі.

Впорядкування нормативно-правової бази у сфері паркування та зберігання автомобільних транспортних засобів повинне здійснюватися 3 урахуванням прийнятих програмних документів. Одним 3 найголовніших таких програмних документів, що стосується сфери паркування та зберігання транспортних засобів, є Національна транспортна стратегія України на період до 2030 року від 30.05.2018 № 430-р. Така стратегія спрямована на запровадження системи покращення пішохідної інфраструктури, паркувальних зон, обмеження швидкості руху транспортних засобів та розвиток інфраструктури для руху велосипедів, покращення сприяння підвищенню міської мобільності та розвитку системи мережі паркувальних зон і пасажирських терміналів для пересадки 3 індивідуального транспорту на міський транспорт [1]. Саме вдосконалення правового регулювання паркування та зберігання автомобільних транспортних засобів $є$ важливою умовою розвитку транспортної системи, а також системи благоустрою, які відіграють важливу роль у створенні сприятливого середовища для життя людей та провадження господарської діяльності, яке $є$ одним 3 найважливіших чинників, що сприяють приливу всіх видів інвестицій до міст України, які в кінцевому результаті і забезпечують їх сталий розвиток.

Непослідовність та суперечливість векторів нормотворчої діяльності у сфері паркування та зберігання транспортних засобів призвела до того, що правове регулювання такої сфери здійснюється розгалуженою системою нормативно-правових актів, які спрямовані на регулювання правовідносин інших галузей, через що виникає значна кількість колізій. У зв'язку з таким станом справ для вдосконалення правового регулювання у цій сфері необхідно сприяти створенню грунтовного наукового базису, на основі якого можна буде провести впорядкування законодавства у цій сфері. Оскільки сфера паркування та зберігання транспортних засобів $є$ комплексною і регулюється нормами різних галузей, необхідно провести кодифікацію законодавства у цій сфері та створити Закон України «Про паркування», який би містив загальні норми, що визначають цілі та принципи правового регулювання суспільних відносин у цій галузі, а також забезпечував взаємоузгодженість усіх норм інших галузей, які застосовуються у правовому регулюванні паркування.

Такий закон покликаний врегулювати колі3ii, пов'язані 3 визначенням понять. Для цього в законі необхідно використовувати запропонований нами вище авторський підхід до визначення понять «паркування» і «паркінг», на основі яких давати визначення іншим поняттям. Крім того, в ньому необхідно передбачити єдину типологію паркінгів та вимоги до них. Все це повинне міститися в першому розділі такого закону.

Другий розділ закону повинен містити норми, які б визначали правовий статус органів, що здійснюють регулювання такої сфери, та регламентували порядок їх взаємодії. У ньому передбачити центральний орган виконавчої влади, який би здійснював державну політику в цій сфері та слідкував за додержанням органами місцевого самоврядування законів у такій сфері. Крім того, закон повинен встановлювати єдині вимоги до осіб, які обіймають посади інспекторів 3 паркування, та чітко розмежовувати їхні повноваження у цій сфері з повноваженнями Національної поліції.

Третій розділ такого закону повинен містити перелік інструментів, за допомогою яких планується розвивати сферу паркування, а також приблизний порядок їх застосування, деталізувати який повинні безпосередньо органи місцевого самоврядування у своїх нормативноправових актах, оскільки кожен населений пункт України має свої специфічні особливості, а тому і порядок застосовування цих інструментів буде відрізнятися.

Завершальний розділ такого закону повинен визначати відповідальність за порушення правил паркування, порядок притягнення до неї, а також відмежовувати звичайні порушення правил паркування від серйозних, за які повинна здійснюватися евакуація транспортних засобів 3 місця порушення.

Також для виконання норм цього закону необхідно передбачити внесення змін та доповнень до законів України «Про місцеве самоврядування в Україні», «Про благоустрій населених пунктів», «Про дорожній рух», «Про автомобільні дороги» та Кодексу України про адміністративні правопорушення.

Висновок. За результатами проведеного дослідження зарубіжного досвіду правового регулювання у сфері паркування та зберігання автомобільних транспортних засобів слід умовно виокремити шість світових моделей правового регулювання паркування та зберігання 
транспортних засобів, серед яких, зважаючи на спільні риси містобудування, схожі початкові умови, за яких відбувся початок реформування галузі паркування, а також тісні економічні та політичні зв'язки, необхідно виділити модель, яка сформувалася в Польщі, як найбільш пріоритетну для застосування в Україні.

Крім того, спираючись на досліджений зарубіжний досвід, можна дійти висновків, що для успіш- ного реформування такої сфери необхідно сприяти активізації роботи зі створення грунтовного в Україні наукового базису регулювання такої сфери, на основі якого можливе створення єдиного кодифікованого закону, який би містив загальні норми, що визначали цілі і принципи правового регулювання такої сфери, забезпечували узгодженість усіх норм інших галузей, які застосовуються у правовому регулюванні такої сфери.

\section{Література}

1. Національна транспортна стратегія України на період до 2030 року : Розпорядження Кабінету Міністрів України від 30 травня 2018 р. № 430-2018 р. Урядовий кур’єр. 2018. № 120.

2. Дослідження ринку послуг утримання майданчиків для паркування та забезпечення зберігання на них транспортних засобів : звіт. Антимонопольний комітет України від 24 листопада 2016. № 88. URL: http://www.amc.gov.ua/amku/doccatalog/document?id=131634\&schema=main.

3. Свропейський досвід законодавчого регулювання у сфері паркування транспортних засобів. Інформаційна довідка. URL: http://euinfocenter.rada.gov.ua/uploads/documents/28994.pdf.

4. Організація паркування в Гельсінкі. Огляд. URL: https://ru-vederko.livejournal.com/1361415.html.

5. Парковки у Варшаві. URL: https://life-globe.com/europe/polsha/varshava/parkovki-v-varshave/.

6. Хавунка Т., Шуварська К., Бризіцька М., Паляниці А. Вирішення проблем завантаженості центральної частини міста та хаотичного: Аналітична записка. Львів : ЛPX, 2017. 53 c. URL: http://spm. ucu.edu.ua/wp-content/uploads/2018/10/lrh_parkuvannya_analitychna-zapyska.pdf.

7. Ison S., Mulley C. Parking Issues and Policies: Emerald Group Publishing Limited, 2014. URL: https://books.google.com.ua/books?id=uP51BAAAQBAJ\&printsec=frontcover\&hl=ru\&source $=$ gbs_ViewAPI\&redir_esc $=\mathrm{y} \# \mathrm{v}=$ onepage $\& \mathrm{q} \& \mathrm{f}=$ false.

8. Solving difficult parking problems with a self-paying meter. URL: https://canadianparking.ca/solvingdifficult-parking-problems-with-a-self-paying-meter/.

9. Wydział Gospodarki Komunalnej Urzędu Miasta Krakowa Program Obsługi Parkingowej dla Miasta Krakowa. Kraków, 2018. URL: https://www.bip.krakow.pl/?mmi=9784\&metka=1.

\section{References}

1. "On approval of the National Transport Strategy of Ukraine for the period up to 2030": Order of the Cabinet of Ministers of Ukraine on the 30th May 2018, Uryadovy Kuryer, 2018. No. 120.

2. Market research services for maintenance of parking lots and storage of vehicles: Report of the Antimonopoly Committee of Ukraine dated November 24, 2016. No. 88. Retrieved from: http://www.amc.gov.ua/amku/ doccatalog/document?id=131634\&schema=main.

3. European experience of legislative regulation in the field of vehicle parking. Information reference. Retrieved from: http://euinfocenter.rada.gov.ua/uploads/documents/28994.pdf.

4. Organization of parking in Helsinki. Review. Retrieved from: https://ru-vederko.livejournal.com/1361415. html.

5. Parking in Warsaw. Retrieved from: https://life-globe.com/europe/polsha/varshava/parkovki-v-varshave/.

6. Havunka, T., Shuvarska, K., Brizitska, M., Palyanytsy, A. Solving the problems of congestion in the central part of the city and the chaotic: Analytical note. Lviv: LRH, 2017. 53 p. Retrieved from: http://spm.ucu. edu.ua/wp-content/uploads/2018/10/lrh_parkuvannya_analitychna-zapyska.pdf.

7. Ison, S., Mulley, C. Parking Issues and Policies: Emerald Group Publishing Limited, 2014. Retrieved from: https://books.google.com.ua/books?id=uP51BAAAQBAJ\&printsec=frontcover\&hl=ru\&source= gbs_ViewAPI\&redir_esc $=\mathrm{y} \# \mathrm{v}=$ onepage $\& \mathrm{q} \& \mathrm{f}=$ false.

8. Solving difficult parking problems with a self-paying meter. Retrieved from: https://canadianparking.ca/ solving-difficult-parking-problems-with-a-self-paying-meter/.

9. Wydział Gospodarki Komunalnej Urzędu Miasta Krakowa Program Obsługi Parkingowej dla Miasta Krakowa. Kraków, 2018. Retrieved from: https://www.bip.krakow.pl/?mmi=9784\&metka=1. 